\title{
Effect of Shade on Arabica Coffee Berry Disease Development: Toward an Agroforestry System to Reduce Disease Impact
}

\author{
J. A. Mouen Bedimo, I. Njiayouom, D. Bieysse, M. Ndoumbè Nkeng, C. Cilas, and J. L. Nottéghem
}

First and second authors: IRAD, Station Polyvalente de Foumbot, BP 665 Bafoussam, Cameroun; third author: CIRAD, UMR BGPI, Campus International de Baillarguet, TA41/k, 34398 Montpellier, cedex 5, France; fourth author: IRAD, Centre de Nkolbisson, BP 2123 Yaoundé Cameroun; fifth author: CIRAD, UPR Maîtrise des bioagresseurs des pérennes, Avenue Agropolis TA-A3/02, 34398, Montpellier, France; and sixth author: SupAgro, UMR BGPI, Campus International de Baillarguet, TA41/k, 34398 Montpellier, cedex 5, France.

Accepted for publication 9 September 2008.

\section{ABSTRACT}

Mouen Bedimo, J. A., Njiayouom, I., Bieysse, D., Ndoumbè Nkeng, M., Cilas, C., and Nottéghem, J. L. 2008. Effect of shade on Arabica coffee berry disease development: Toward an agroforestry system to reduce disease impact. Phytopathology 98:1320-1325.

Coffee berry disease (CBD), caused by Colletotrichum kahawae, is a major constraint for Arabica coffee cultivation in Africa. The disease is specific to green berries and can lead to $60 \%$ harvest losses. In Cameroon, mixed cropping systems of coffee with other crops, such as fruit trees, are very widespread agricultural practices. Fruit trees are commonly planted at random on coffee farms, providing a heterogeneous shading pattern for coffee trees growing underneath. Based on a recent study of $\mathrm{CBD}$, it is known that those plants can reduce disease incidence. To assess the specific effect of shade, in situ and in vitro disease development was compared between coffee trees shaded artificially by a net and trees located in full sunlight. In the field, assessments confirmed a reduction in CBD on trees grown under shade compared with those grown in full sunlight. Artificial inoculations in the laboratory showed that shade did not have any effect on the intrinsic susceptibility of coffee berries to CBD. Coffee shading mainly acts on environmental parameters in limiting disease incidence. In addition to reducing yield losses, agroforestry system may also be helpful in reducing chemical control of the disease and in diversifying coffee growers' incomes.

Additional keywords: barrier effect, splash dispersal.

Plant disease epidemiology studies in complex plant communities, such as rain forest, are very few, although this topic appears crucial for developing sustainable land-use strategies (23). For example, it is suspected that plant density makes the difference for South American leaf blight (SALB) between natural Amazonian forest, where there is nearly no damage, and monospecific plantations, where the levels of damage are often very high (20); however, this hypothesis was never reinforced by appropriate studies. In the case of cocoa, coffee, or tea plantations, agroforestery systems could also modify pests and disease incidence compared with monospecific plantations, and the effect of shade trees on diseases could have several explanations $(5,6,20,41)$. Annual crop associations are another case of complex plant communities and several studies concerned plant physiology or resource partitioning (15) but, even for these simple cases, few epidemiological studies were carried out.

The Arabica coffee tree is a shade-growing plant in its natural biotope (32). In order to ensure its adequate development in new growing zones, its domestication has often required the establishment of shade plants, such as Leucaena, Albizzia, Acacia, or Erythrina spp. Shade level depends on tree species and pruning intensity and can vary widely, from 30 to $70 \%$, but cultivation in full sunlight also exists in many regions $(25,37)$. The percentage of shade and the species of the shade tree has an incidence on the intensity of the epidemic of some diseases such as American leaf spot epidemics in Central America, for which the level increases with shade (2). In Africa, this plant of great socioeconomic im-

Corresponding author: C. Cilas; E-mail address: christian.cilas@cirad.fr

doi:10.1094/PHYTO-98-12-1320

(c) 2008 The American Phytopathological Society portance is subject to highly destructive parasite attacks by (CBD) (47). It is a disease specific to green berries and has only been found to date in African production zones (26). It has a high incidence in highland regions $(>1,600 \mathrm{~m})$, where it can cause up to $\approx 60 \%$ harvest losses $(8,31)$. Mummified berries, twig bark, and dead branches are considered to be primary inoculum sources for the disease $(31,35,45)$. However, it is still not clear how the pathogen survives between two production seasons (28). CBD occurs as dark necrotic, sunken spots, sometimes with orangecolored acervuli. Most infected berries fall prematurely; some remain attached to the branches, thereby forming secondary sources of inoculum capable of causing fresh contamination.

As for all anthracnose diseases, CBD development depends on climatic factors such as rainfall, temperature, and relative humidity $(11,17,21,34)$. Rainfall is the main agent of Colletotrichum spp. conidium dispersal $(18,28,46)$. Most conidia of $C$. kahawae can be effectively dispersed by an optimum rainfall of $10 \mathrm{~mm}$ but heavy rainfall leads more to their leaching from the coffee tree canopy to the soil (46). Relative humidity close to saturation and optimum temperatures of 20 to $22^{\circ} \mathrm{C}$ are conducive to their germination and appressorium formation $(16,26)$. Colletotrichum spp. conidium germination can occur $24 \mathrm{~h}$ after conidia enter into contact with the tissues of the host plant $(9,14)$. There then follows elongation of the germ tubes, whose apical section later differentiates into an appressorium $(4,12,24,42)$. The infection hyphae arising from those appressoria then colonize the contaminated fruit, causing necrosis of the tissues on which new acervuli form.

CBD epidemics are polycyclic and recurrent from one year to the next $(28,31,45)$. They usually coincide with the annual fruiting cycle of the coffee trees, itself highly dependent upon the Colletotrichum kahawae, which causes coffee berry disease 
rainfall pattern of infested regions. For example, in Kenya, where the bimodal rainfall pattern encourages two annual fruiting cycles, CBD epidemics develop in two main annual cycles that overlap. On the other hand, the disease only has one annual development cycle in regions where the coffee trees flower once, as in the highlands of West Cameroon, which has a monomodal rainfall pattern. In these regions, the disease develops over time following three main sequences: (i) a phase of slow progression after the first infected berries appear in the 8th to 10th week after flowering; (ii) a phase of exponential progression between the 10 th and 21 st week after flowering, corresponding to the period of fruit formation; and (iii) an asymptotic phase at approximately the 22 nd week after flowering (i.e., at the beginning of the fruit hardening period) (29).

In Cameroon, on small family coffee farms, shade plants mostly consist of various fruit trees planted randomly among the coffee trees, thereby shading the coffee trees in a fairly heterogeneous way. Such plants can limit the development of coffee leaf rust caused by Hemileia vastatrix (3) or CBD $(22,30,38)$. Based on recent epidemiological studies conducted on CBD in Cameroon (30), we put forward two main hypotheses regarding reduced disease incidence under shade plants: either they form a physical barrier to effective dispersal of the pathogen's conidia or they affect the physiology of berries and, consequently, their receptiveness to C. kahawae. Consequently, epidemiological monitoring of CBD was undertaken in 2005 in Cameroon on coffee trees shaded by nets to provide defined, consistent shade treatments, and trees exposed to full sunlight. This study was conducted at the same time as artificial inoculations in the laboratory on berries taken from those different coffee trees. The purpose of these experiments was to assess the specific effect of permanent, uniform shading on CBD development in zones with very strong infection pressure. They were also to determine the impact of this coffee-growing method on the intrinsic susceptibility of berries to the disease over time.

\section{MATERIALS AND METHODS}

Epidemiological monitoring in the field. Planting material. The field experiments were conducted in a smallholding in Bafou $\left(05^{\circ} 33.540 \mathrm{~N}, 10^{\circ} 04.520 \mathrm{E}, 1,820 \mathrm{~m}\right.$ above sea level $)$, located in the highlands of West Cameroon. Thirty-four coffee trees were identified inside the plantation planted with CBD-susceptible cultivars (cv. Jamaica). In order to control shading conditions so that all the coffee trees studied in the field were placed under the same expanse and density of shade, permanent artificial shade was provided by black shade netting with a regular mesh allowing $50 \%$ of the light to filter through (Tildennet EC 50\%, Tilden Industries, U.K.). Half of the coffee trees were placed individually under shade netting, each paired with immediately adjacent trees in full sunlight. Epidemiological monitoring in the field was carried out using three plagiotropic branches with at least five glomerules were marked on each of the coffee trees (i.e., one branch in the upper storey, one in the middle storey, and one in the lower storey).

Weekly observations were carried out on the marked branches from the 6th to 24th week after flowering (from 27 April to 25 August 2005) (i.e., 19, observations in all). They consisted of counting (i) the total number of berries (Btot), (ii) the number of new diseased berries and their marking with small labels (Bdis), and (iii) old diseased berries (already marked) (Bmark).

For each coffee tree in the study, the different harvest losses were estimated by three methods.

(i) The percentage of total losses (Ltot) expressed all the losses due to $\mathrm{CBD}$ or not, recorded over a year. It was calculated by the formula Ltot $=\left[\right.$ Btot $_{1}-\left(\right.$ Btot $_{n}-$ Bmark $_{n}-$ Bdis $\left._{n}\right) /$ Btot $\left._{1}\right] \times 100$, where Btot $_{1}$ indicates the total number of berries on the first inspection and the expression $\left(\mathrm{Btot}_{n}-\mathrm{Bmark}_{\mathrm{n}}-\mathrm{Bdis}_{\mathrm{n}}\right)$ the num- ber of healthy berries in the last week of observations. The terms Btot $_{n}, B$ mark $_{n}$, and Bdis $s_{n}$ represent the total number of berries, the total number of marked diseased berries and the total number of newly infected berries on the final inspection.

(ii) The percentage of diseased berries (Pdis) was the ratio between the sum of newly diseased berries counted over all the weeks of observations $\left(\sum\right.$ Bdis $\left._{1-n}\right)$ and the initial number of berries $\left(\right.$ Btot $\left._{1}\right):$ Pdis $=\left(\Sigma\right.$ Bdis $_{1-\mathrm{n}} /$ Btot $\left._{1}\right) \times 100$.

(iii) The percentage of losses not due to CBD (Pfall) was expressed by the difference between total losses and losses due to CBD (Ploss - Pdis). These losses were called "physiological fall" because they were mainly due to the falling of apparently healthy berries.

Experimental design and observations. This study was conducted in a split-plot (two-way) factorial experimental design which comprised 16 replicates. The main factor was shade (full sun or $50 \%$ shade) and the secondary factor was the different storeys in the coffee trees (upper, intermediate, and lower storey). Each coffee tree amounted to one replicate.

Artificial inoculations in the laboratory. Plant material. Green coffee berries were sampled from the shade and in fullsunlight treatments, using trees that had been especially reserved for green berry sampling, for artificial inoculations in the laboratory. The samples were taken from three storeys of the coffee trees (upper, middle, and lower) in the 12th, 16th, 18th, and 22nd weeks after flowering. On each sampling operation, 125 berries were taken per storey (i.e., 375 berries per tree). Susceptible and tolerant controls were introduced to check inoculation validity. Berries were taken from the field-tolerant cv. Java and the highly susceptible cv. Caturra. The samples were taken from plants grown in full sunlight in the varietal collection at IRAD's Santa station in Northwest Cameroon.

The berries taken from each storey of the four coffee trees in the study were divided between five petri dishes lined with blotting paper imbibed with sterile distilled water at a rate of 25 berries per dish (i.e., five replicates of 25 berries per storey).

Plant pathogen and inoculation technique. The isolate of $C$. kahawae was obtained from infected berries of a coffee tree in the Bafou plot. It was purified by monoconidial culturing in a petri dish on potato-dextrose-agar (PDA) medium. The isolate arising from the culture displayed relatively slow radial growth and a woolly, dark-gray mycelium after 10 days of storage at $22^{\circ} \mathrm{C}$ with a 12 -h photoperiod. Its pathogenicity was tested beforehand on detached berries before its routine use in actual artificial inoculations. The inoculum consisted of a filtrate of the conidial suspension obtained by scraping pure cultures of the isolate imbibed with sterile distilled water. It was calibrated at $10^{6}$ conidia/ml prior to inoculation. A $10-\mu l$ droplet was then deposited on each of the berries using a micropipette. After inoculation, the berries were incubated in a climatic chamber (phytotron) regulated to a temperature of $21^{\circ} \mathrm{C}$ with a 12-h photoperiod.

Experimental design and observations. Three main factors were studied during this experiment: (i) origin of the artificially inoculated berries (shaded coffee tree, coffee tree in full sunlight, Java coffee tree [tolerant control], and Caturra coffee tree [susceptible control]; (ii) coffee tree storey (upper, middle, and lower); and (iii) berry age at the time of artificial inoculation.

Observations began $24 \mathrm{~h}$ after inoculation and continued for 10 successive days. The 10-day observation period limited the risk of confusing CBD symptoms with infections by opportunistic fungi such as Pestalotia spp. Thus, daily observations consisted in counting the total number of diseased berries in each petri dish.

Evaluation of berry susceptibility in vitro. The data gathered enabled us to calculate the berry infection rate $\left(\mathrm{Rt}_{\text {inf }}\right)$ and the index of infection precocity $\left(\operatorname{Ind}_{\mathrm{p}}\right)$ per petri dish. The infection rate corresponded to the percentage of successful inoculations on the tenth day of observations. It was obtained by formula $\mathrm{Rt}_{\mathrm{inf}}=$ 
$\left(\right.$ Bdis $\left._{10} \times 100\right) / N$, where Bdis $_{10}$ was the total number of diseased berries counted in the petri dish on the 10th day of observations and $\mathrm{N}$ was the total number of inoculated berries $(N=25)$.

The infection precocity index was an estimation of the speed with which symptoms occurred after inoculation. It was calculated from the following formula, based on that used by (40), to calculate the production precocity index for mango: $\operatorname{Ind}_{\mathrm{p}}=$ $\left(6 \mathrm{X}_{5}+5 \mathrm{X}_{6}+4 \mathrm{X}_{7}+3 \mathrm{X}_{8}+2 \mathrm{X}_{9}+\mathrm{X}_{10}\right) / 6(\Sigma \mathrm{Nmal})$.

The variables $X_{5}, X_{6}, X_{7}, X_{8}, X_{9}$, and $X_{10}$ represented the number of new berries displaying symptoms on the 5th, 6th, 7th, 8th, 9th, and 10th day after inoculation, respectively, because the first symptoms on the most susceptible berries occurred on the fifth day of observations. The coefficients $6,5,4,3,2$, and 1 , which corresponded to an arithmetic progression of reason -1 (minus one), were attributed in that order to each variable $X_{i+1}$, in order to give greater weight to berries attacked early. The term $\Sigma$ Ndis was the sum of new diseased berries counted between the 5 th and 10th day of observations. In reality, that term was equivalent to variable Bdis $_{10}$ used to calculate the infection rate. The infection precocity index $\left(\operatorname{Ind}_{\mathrm{p}}\right)$ was 1 (one) if all the infected berries were counted on the fifth day of observations. It was 0.16667 , a 6th, if all the inoculated berries did not display symptoms until the 10th day of observations.

Statistical analyses. In order to comply with conditions for applying an analysis of variance, all the data expressed as percentages, after analysis of the residuals, were $\arcsin \sqrt{x}$ transformed. The analysis of variance was performed with the general linear model (GLM) procedure of the Statistical Analysis System (SAS) software (version 9.1). Means between the factors studied were studied by the Student-Newman-Keuls test at $5 \%$.

\section{RESULTS}

Characterization of harvest losses. Losses due to CBD varied very significantly $(P<0.0001)$ depending on coffee tree shading. Likewise, those losses differed significantly $(P=0.0499)$ depending on the storeys, whatever the coffee tree shading. On the other hand, no significant difference was found between the factors studied for losses due to physiological fall (Table 1). The infection rate for coffee trees under artificial shade, estimated at $30 \%$ of diseased berries, was well below that for the coffee trees without shade, which had $\approx 50 \%$ of diseased berries (Table 2). In addition, berries from the lower branches of the coffee trees were significantly less attacked than those from the middle and upper branches, which were part of the same uniform group of means (Table 2).

The first diseased berries were seen in the ninth week after flowering, whatever the coffee tree shading (Fig. 1). Then, the new infection rate progressed in the same way in shade and sunlight up to the 11 th week, when $\approx 3 \%$ of new infections were recorded on all the coffee trees. Between the 12th and 16th week after flowering, the weekly rate of newly infected berries on coffee trees in full sunlight was clearly greater than for the trees under the shade netting. The disease peak was reached in the 14th week, with $\approx 11 \%$ of new diseased berries found on the coffee trees exposed to full sunlight. That disease rate corresponded to double that recorded on shaded coffee trees. All the coffee trees displayed the same new infection rate between the 17th and 24th week, whatever the shade. New infections decreased considerably (under 1\%) from the 20th week after flowering onward.

Disease development on berries inoculated artificially in the laboratory. The analysis of variance results (Table 3 ) show that all the main factors studied (coffee tree cultivars, branch storey, and berry age) had a highly significant effect $(P<0.0001)$ on the infection rate and on the disease precocity index. The same applied for the different interactions between those factors. However, the effect of the main factors remained highly preponderant, given the large values of the $F$ test, which were sometimes more than 10 times those of the interactions. According to the StudentNewman-Keuls test, the disease was significantly more severe and occurred earlier on berries of the Caturra coffee tree (susceptible control) than on berries of the other coffee trees. The lowest infection rate $(41.7 \%)$ and precocity index $(0.36)$ were found for berries from the Java coffee tree (tolerant control). Berries from coffee trees under artificial shade displayed an intermediate disease level and precocity index which were statistically equivalent to those of berries from trees exposed to sunlight. This means separation test also brought out rising severity and precocity gradients for the disease depending on the coffee tree storeys.

TABLE 2. Comparison of harvest loss means depending on coffee tree shading and the position of their branches (field monitoring)

\begin{tabular}{lcc}
\hline Parameters studied & $\begin{array}{c}\text { Losses caused by } \\
\text { coffee berry disease }(\%)\end{array}$ & $\begin{array}{c}\text { Physiological fall } \\
(\%)\end{array}$ \\
\hline $\begin{array}{l}\text { Lighting } \\
\text { Trees under shade netting }\end{array}$ & $29.56 \mathrm{~b}$ & $32.56 \mathrm{a}$ \\
Trees in full sunlight & $49.89 \mathrm{a}$ & $35.37 \mathrm{a}$ \\
Position & $44.22 \mathrm{a}$ & $34.51 \mathrm{a}$ \\
Upper branches & $42.34 \mathrm{a}$ & $36.80 \mathrm{a}$ \\
Middle branches & $32.61 \mathrm{~b}$ & $30.59 \mathrm{a}$ \\
\hline Lower branches &
\end{tabular}

${ }^{\mathrm{z}}$ Coffee tree lighting and position of coffee tree branches.

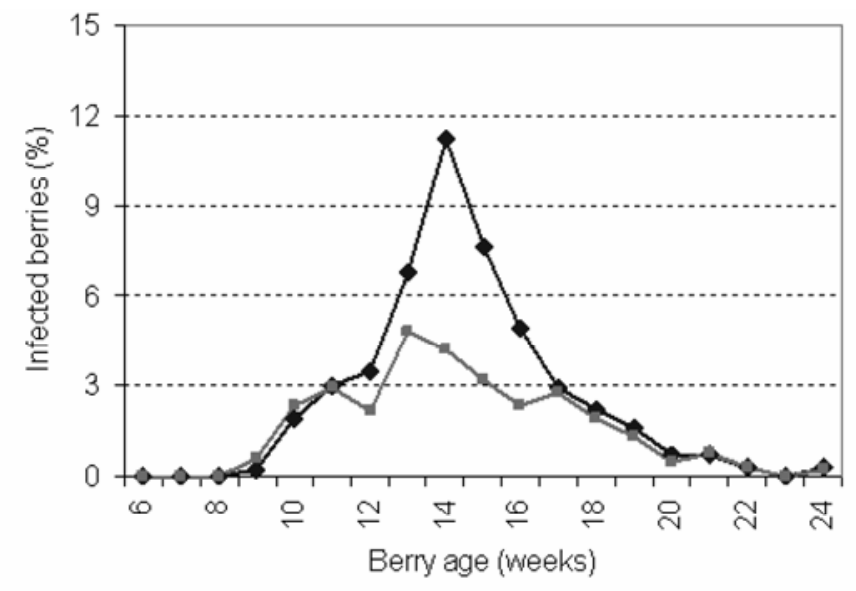

$\neg$ Coffee trees in full sunlight $-\longrightarrow$ Coffee trees under shade netting

Fig. 1. Appearance of new diseased berries over time depending on coffee tree shading (in 2005).

TABLE 1. Analysis of variance for losses caused by coffee berry disease (CBD) and those due to physiological fall (field monitoring)

\begin{tabular}{lccccc}
\hline & & \multicolumn{2}{c}{ Losses caused by CBD } & \multicolumn{2}{c}{ Physiological fall } \\
\cline { 3 - 6 } Source of variation & df & $F$ test & 17.31 & $P>F$ & \multicolumn{2}{c}{$P$ test } & 0.25 & 0.6183 \\
Coffee tree lighting & 1 & 3.10 & $<0.0001$ & 0.46 & 0.6327 \\
Position of branches & 2 & 1.45 & 0.0499 & 0.77 & 0.4674 \\
Lighting $\times$ position & 2 & $\ldots$ & 0.2402 & $\ldots$ & $\ldots$ \\
Error & 90 & $\ldots$ & $\ldots$ & $\ldots$ \\
\hline
\end{tabular}


However, berry susceptibility varied greatly over time, with the lowest infection rate and precocity index being observed in the 22nd week after flowering (Table 4).

During the first three series of artificial inoculations (Fig. 2), berries from coffee trees exposed to sunlight displayed the same infection rates as those from shaded coffee trees. However, in the 22nd week after flowering, berries from coffee trees exposed to sunlight proved to be more susceptible to CBD than those from shaded coffee trees. Berries from the CBD-susceptible control (Caturra) were more attacked than those from all the other coffee trees in the 16th and 22nd week. They displayed the same infection rate as berries from trees under shade and in full sunlight in the 12th and 18th week after flowering. The lowest infection rates were always found on berries from the disease-tolerant control (Java), regardless of the series of artificial inoculations considered. Yet the berries of that control, and those of shaded coffee trees, had the same infection rate after inoculation in the 22nd week after flowering (Fig. 2). Regardless of their age, berries taken from coffee trees in full sunlight displayed varying susceptibility to the disease following a rising gradient depending on the position of the branches in the coffee tree (Fig. 3B). That susceptibility gradient was also seen for berries from shaded coffee trees, except for those of the 12th week taken from upper and middle branches, which had the same degree of susceptibility to the disease (Fig. 3A). All the berries from upper branches of unshaded coffee trees were attacked after artificial inoculation in the 12 th week after flowering.

\section{DISCUSSION}

Artificial shade placed over the coffee trees considerably reduced CBD development. Epidemiological monitoring showed that coffee trees in full sunlight were more severely attacked than coffee trees covered with shade netting. On the other hand, artificial inoculations of detached berries showed that, under our experimental conditions, the intrinsic susceptibility of berries to the disease was not significantly different between shaded and unshaded coffee trees (Fig. 2). The shade effect can work in various manners (41): shade reduces sunlight and particularly UV-B, which plays an important role on some plant diseases such as blister blight of tea (19); shade modifies the microenvironmental conditions (reduced temperature, reduced temperature fluctuations, reduced air movements, and increased humidity) and creates a "phylloclimate" able to perturb interactions between pathogens and target organs (10); and shade can also work as a barrier and can limit the splash dispersal of the pathogen (33). With our results, we conclude that the preponderant influence of shade netting is on the epidemic parameters in the C. kahawaeCoffea arabica pathosystem, which tallies with the "barrier effect" hypothesis whereby shade plants limit CBD dispersal (30, 38). In fact, in our study, shade did not induce any change in the intresinc susceptibility of berries to CBD by artificial inoculations of detached berries. Actually, shade could limit the rain intensity and, consequently, the splash dispersal of Colletotrichum kahawae, as has been already mentioned in other studies for several pathogens and, particularly, Colletotrichum spp. $(13,33,34,48,49)$.
In the field or in the laboratory, berry susceptibility over time varied in the same way regardless of shade treatment (Figs. 1 and 2 ). Other studies suggest that berry ripening may occur faster in coffee trees exposed to full sunlight than in shaded trees (44) but the effect of shading on berry development did not appear to affect their receptiveness to $C$. kahawae susceptibility. Furthermore, the peak of the CBD epidemic in the field (14th week after flowering) did not coincide with the maximum berry susceptibility period (18th week after flowering). The peak in new CBD infections appeared to coincide with the period of maximum inoculum pressure and suitable climatic conditions. In the case of polycyclic epidemics such as CBD, the inoculum pressure in plantations increases in line with the appearance of new receptive organs, especially when the fruiting and pathogen dispersal parameters are optimum $(39,50)$. Thus, inoculum pressure re-

TABLE 4. Means for the infection level and precocity index per type of coffee tree, by storey and by berry age (artificial inoculations)

\begin{tabular}{lcc}
\hline Parameters studied & Infection rate $(\%)$ & Infection precocity \\
\hline Type of coffee trees & & \\
Cv. Caturra (control) & $75.800 \mathrm{a}$ & $0.588 \mathrm{a}$ \\
Cv. Jamaica under shade & $59.923 \mathrm{~b}$ & $0.471 \mathrm{~b}$ \\
Cv. Jamaica in sunlight & $58.305 \mathrm{~b}$ & $0.470 \mathrm{~b}$ \\
Cv. Java (témoin) & $41.695 \mathrm{c}$ & $0.358 \mathrm{c}$ \\
Position of coffee tree branches & & \\
$\quad$ Upper branches & $74.880 \mathrm{a}$ & $0.517 \mathrm{a}$ \\
Middle branches & $59.117 \mathrm{~b}$ & $0.467 \mathrm{~b}$ \\
Lower branches & $43.538 \mathrm{c}$ & $0.434 \mathrm{c}$ \\
Berry age & & \\
12th week & $59.649 \mathrm{~b}$ & $0.463 \mathrm{c}$ \\
16th week & $67.579 \mathrm{~b}$ & $0.473 \mathrm{~b}$ \\
18th week & $74.596 \mathrm{a}$ & $0.560 \mathrm{a}$ \\
22nd week & $34.915 \mathrm{c}$ & $0.395 \mathrm{~d}$ \\
\hline
\end{tabular}

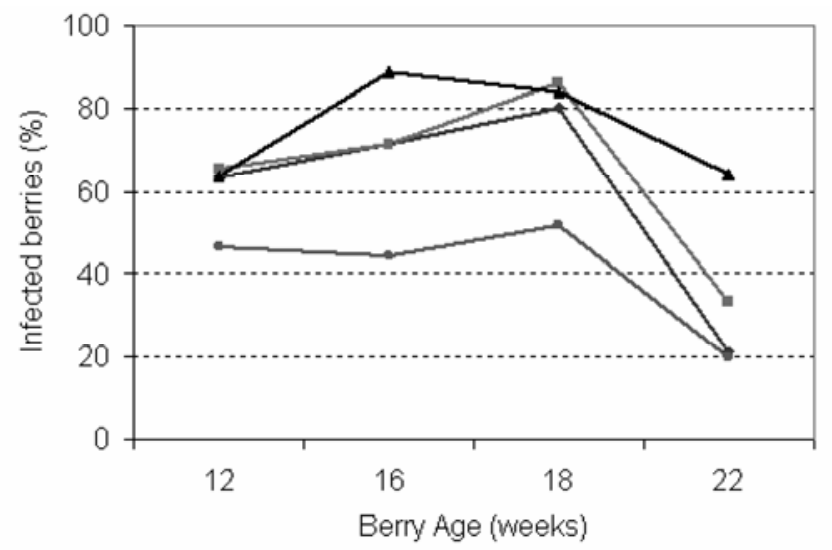

\section{$\rightarrow$ Jamaica berries under shade $\rightarrow$ Jamaica berries in full sunlight Susceptible control (Caturra) $\rightarrow$ Tolerant control (Java)}

Fig. 2. Berry infection rate, depending on the coffee trees, on different artificial inoculation dates.

TABLE 3. Analysis of variance for the infection level and disease precocity index (artificial inoculations) ${ }^{\mathrm{z}}$

\begin{tabular}{|c|c|c|c|c|c|}
\hline \multirow[b]{2}{*}{ Source of variation } & \multirow[b]{2}{*}{ df } & \multicolumn{2}{|c|}{ Infection rate } & \multicolumn{2}{|c|}{ Infection precocity } \\
\hline & & $F$ test & $P>F$ & $F$ test & $P>F$ \\
\hline Type of coffee trees & 3 & 109.74 & $<0.0001$ & 123.64 & $<0.0001$ \\
\hline Coffee tree storey & 2 & 218.90 & $<0.0001$ & 35.31 & $<0.0001$ \\
\hline Trees $\times$ storey & 6 & 10.41 & $<0.0001$ & 8.61 & $<0.0001$ \\
\hline Trees $\times$ berry age & 9 & 11.96 & $<0.0001$ & 22.82 & $<0.0001$ \\
\hline Storey $\times$ berry age & 6 & 2.17 & 0.479 & 6.38 & $<0.0001$ \\
\hline
\end{tabular}

${ }^{\mathrm{z}}$ Coefficient of variation $=13.79$ and $13.86 \%$ for infection rate and precocity, respectively. 
mains highly dependent upon climatic factors, such as the temperature, relative humidity and rainfall $(1,27,36,43)$.

Field observations revealed that there was a rising gradient of disease severity regardless of coffee tree shading. That gradient appeared to be due to more efficient $C$. kahawae conidium dispersal on berries in the canopy compared with those in the lower storeys (30). The same type of gradient was found for intrinsic berry susceptibility, following the artificial inoculations carried out in vitro. This result confirmed disease distribution on a coffee tree scale, as revealed by observations in the field. However, it also indicated that berries on the upper branches are apparently naturally more receptive to $C$. kahawae aggression than on the lower branches. For other fruit diseases, often there also are differences between trunk and canopy in term of severity but it is more common that the fruit on the canopy are less attacked than the fruit on the trunk or on the lower storeys, such as for Phytophthora disease on cacao (7), because of the microclimate being dryer on the canopy.

This study confirmed that shade plants grown with coffee trees could considerably reduce losses due to CBD. They probably act as a physical barrier to efficient pathogen dispersal on coffee trees. However, shade plants do not appear to have any effect on the intrinsic susceptibility of berries to CBD. Reducing losses caused by the disease through the use of shade plants is an original prospect for reducing CBD impact, because the incidence of fungal diseases is often greater under shade (2). However, it would be worth confirming our results under other agroecological conditions where CBD thrives. Interactions with interplanted perennial plants should also be studied, in terms of both agroecological relations and health (23), in order to optimize agro-
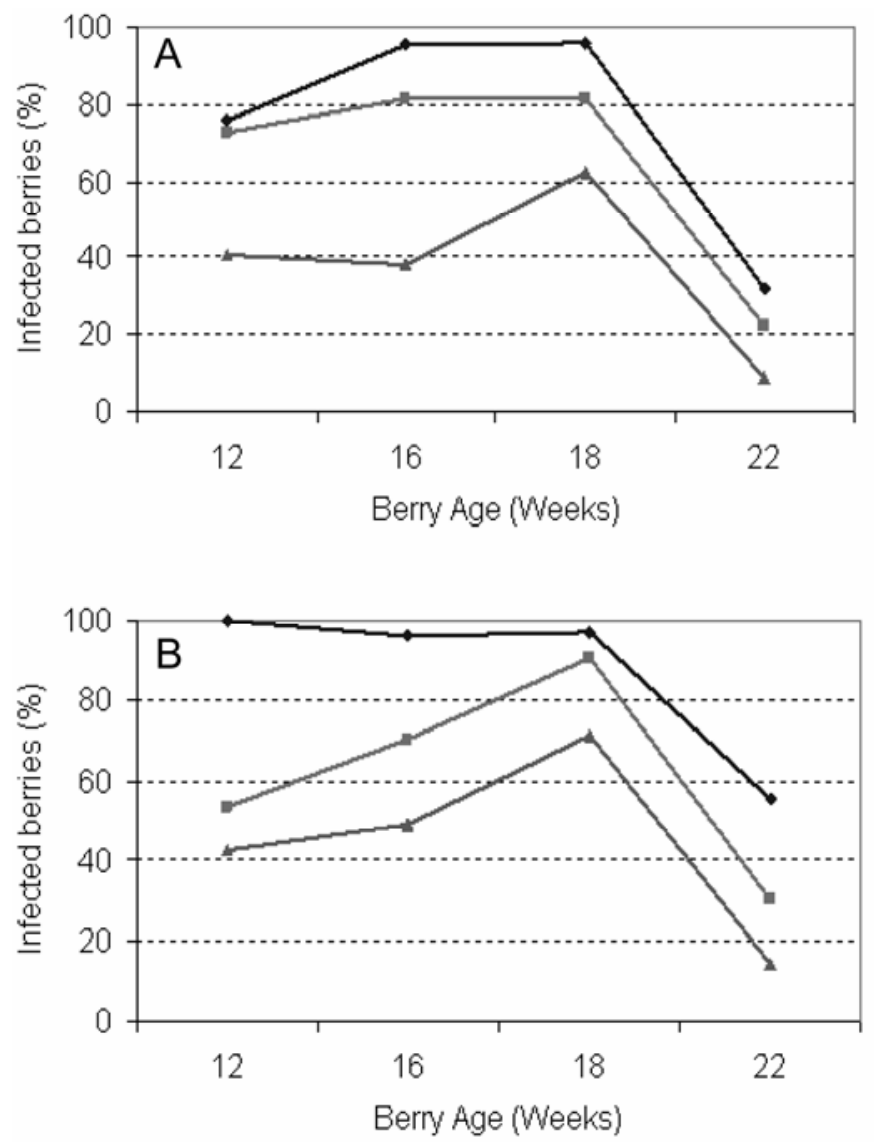

$\rightarrow$ Upper branches $\rightarrow$ Middle branches $\multimap$ Lower branches

Fig. 3. Berry infection rate, depending on the storeys, on different artificial inoculation dates for $\mathbf{A}$, trees under shade and $\mathbf{B}$, trees in full sunlight. forestry systems (choice of species and planting designs). This study suggests that an agroforestry system could be established to assess how such a system might reduce CBD incidence in areas where the disease has a strong impact.

\section{ACKNOWLEDGMENTS}

This study was funded by the European Union (Inco-Dev/CBD-Resist project). We thank J. P. Deumeni and the observation teams at the IRAD stations at Santa and Foumbot (Cameroon) for data gathering and P. F. Mouen Bedimo for data entry and verification.

\section{LITERATURE CITED}

1. Agostini, J. P., Bushong, P. M., Bhatia, A., and Timmer, L. W. 2003. Influence of environmental factors on severity of Citrus scab and melanose. Plant Dis. 87:1102-1106.

2. Avelino, J., Cabut, S., Barboza, B., Barquero, M., Alfaro, R., Esquivel, C., Durand, J.-F., and Cilas, C. 2007. Topography and crop management are key factors for the development of American leaf spot epidemics on coffee in Costa Rica. Phytopatology 97:1532-1542.

3. Avelino, J., Willocquet, L., and Savary, S. 2004. Effects of crop management patterns on coffee rust epidemics. Plant Pathol. 53:541-547.

4. Bailey, J. A., O'Connell, R. J., Pring, R. J., and Nash, C. 1992. Infection strategies of Colletotrichum species. Pages 88-120 in: Colletotrichum: Biology, Pathology, and Control. J. A. Bailey and M. J. Jeger, eds. CAB International, Wallingford, UK.

5. Beer, J. 1987. Advantages, disadvantages and desirable characteristics of shade trees for coffee, cacao and tea. Agrofor. Syst. 5:3-13.

6. Beer, J., Muschler, R., Kass, D., and Somarriba, E. 1998. Shade management in coffee and cacao plantations. Agrofor. Syst. 38:139-164.

7. Berry, D., and Cilas, C. 1994. Etude génétique de la réaction à la pourriture brune des cabosses chez des cacaoyers issus d'un plan de croisements diallèle. Agronomie 14:599-609.

8. Bieysse, D., Bella Manga, Mouen Bedimo, J. A., Ndeumeni, J. P., Roussel, V., Fabre, J. V., and Berry, D. 2002. L'anthracnose des baies une menace potentielle pour la culture mondiale de l'Arabica. Plant. Rech. Dév. May 2002:145-152.

9. Binyamini, N., and Schiffmann-Nadel, M. 1972. Latent infection in avocado fruits due to Colletotrichum gloeosporioides. Phytopathology 62:592-594.

10. Chelle, M. 2005. Phylloclimate or the climate perceived by individual plant organs: What it is? How to model it? What for? New Phytol. 166:781-790.

11. Denham, T. G., and Waller, J. M. 1981. Some epidemiological aspects of post-bloom fruit drop disease (Colletotrichum gloeosporioides) in citrus. Ann. Appl. Biol. 98:65-77.

12. Emmet, R. W., and Parbery, D. G. 1975. Appressoria. Annu. Rev. Plant Pathol. 23:421-454.

13. Evenhuis, A., Verdam, B., and Zadocks, J. C. 1997. Splash dispersal of conidia of Mycocentrospora acerina in the field. Plant Pathol. 46:459-469.

14. Fagan, H. J. 1970. Postbloom fruit drop, a new disease of citrus associated with a form of Colletotrichum gloeosporioides. Ann. Appl. Biol. 91:13-20.

15. Fridley, J. D. 2003 Diversity effects on production in different light and fertility environments: An experiment with communities of annual plants. J. Ecol. 91:396-406.

16. Gibbs, J. N. 1969. Inoculum sources for coffee berry disease. Ann. Appl. Biol. 64:515-522.

17. Goos, R. D., and Tschirch, M. 1962. Effect of environmental factors on spore germination, spore survival, and growth of Gloeosporioides musarum. Mycologia 54:353-366.

18. Griffiths, E., and Waller, J. M. 1971. Rainfall and cropping patterns in relation to coffee berry disease. Ann. Appl. Biol. 67:75-91.

19. Gunasekera, T. S., Paul, N. D., and Ayres, P. G. 1997. The effects of ultraviolet-B (UV-B: $290-320 \mathrm{~nm}$ ) radiation on blister blight disease of tea (Camellia sinensis). Plant Pathol. 46:179-185.

20. Guyot, J., Cilas, C., and Sache, I. 2008. Influence of host resistance and phenology on South American leaf blight of the rubber tree with special consideration of temporal dynamics. Eur. J. Plant Pathol. 120:111-124.

21. Guyot, J., Ntawanga Omanda, E., Ndoutoume, A., Mbah Otsaghe, A.-A., Enjalric, F., and Ngoua Assoumou, H.-G. 2001. Effect of controlling Colletotrichum leaf fall of rubber tree on epidemic development and rubber production. Crop Prot. 20:581-590.

22. Hillocks, R. J., Phiri, N. A., and Overfield, D. 1999. Coffee pest and disease management options for smallholders in Malawi. Crop Prot. 18:199-206. 
23. Holdenrieder, O., Pautasso, M., Weisberg, P. J., and Lonsdale, D. 2004. Tree diseases and landscape processes: The challenge of landscape pathology. Trends Ecol. Evol. 19:446-452.

24. Jeffries, P., Dodd, J. C., and Plumbey, R. A. 1990. The biology and control of Colletotrichum species on tropical fruit crops. Plant Pathol. 39:343-366.

25. Kuffa, T., Shimber, T., Yilma, A., Netsere, A., and Taye, E. 2001. The impact of close spacing on yield of arabica coffee under contrasting agroecologies of Ethiopia. Afr. Crop Sci. J. 9:401-409.

26. Masaba, D., and Waller, J. M. 1992. Coffe berry disease: The current statut. Pages 237-249 in: Colletotrichum: Biology, Pathology and Control. J. A. Baley and M. J. Jeger, eds. CAB International, Wallingford, UK.

27. Mila, A. L., Driever, G. F., Morgan, D. P., and Michailides, T. J. 2005. Effect of latent infection, temperature, precipitation and irrigation on panicle and shoot blight of pistachio in California. Phytopathology 95:926-932.

28. Mouen Bedimo, J. A. 2006. Dynamique spatio-temporelle de l'anthracnose des baies du caféier arabica due à Colletotrichum kahawae (Waller \& Bridge), au Cameroun: Analyse des principaux facteurs déterminants de la maladie. Ph.D. thesis, ENSA, Montpellier, France.

29. Mouen Bedimo, J. A., Bieysse, D., Cilas, C., and Nottéghem, J. L. 2007. Spatio-temporal dynamics of arabica coffee berry disease due to Colletotrichum kahawae on a plot scale. Plant Dis. 91:1229-1236.

30. Mouen Bedimo, J. A, Bieysse, D., Njiayouom, I., Deumeni, J. P., Cilas, C., and Nottéghem, J. L. 2007. Effect of cultural practices on the development of arabica coffee berry disease, caused by Colletotrichum kahawae. Eur. J. Plant Pathol. 119:391-400.

31. Muller, R. A. 1980. Contribution à la connaissance de la phytomycocénose constituée par Coffea arabica L., Colletotrichum coffeanum Noack (sensu Hindorf), Hemileia vastatrix B. et Br., Hemileia coffeicola Maublanc et Roger. Institut français du café et du cacao, Bull. No. 15. Paris.

32. Muschler, R. G. 2004. Shade management and its effect on coffee growth and quality. Pages 391-418 in: Coffee Growing, Processing, Sustainable Production. A Guide Book for Growers, Processors, Traders and Researchers. J. N. Wintgens, eds.

33. Ntahimpera, N., Ellis, M. A., Wilson, L. L., and Madden, L. V. 1998. Effects of a cover crop on splash dispersal of Colletotrichum acutatum conidia. Phytopathology 88:536-543.

34. Ntahimpera, N., Wilson, L. L., Ellis, M. A., and Madden, L. V. 1999. Comparison of rain effects on splash dispersal of three Colletotrichum species infecting strawberry. Phytopathology 89:555-563.

35. Nutman, F. J., and Roberts, F. M. 1960. Investigations on a disease of Coffea Arabica caused by a form of Colletotrichum Noack. I-Some factors affecting infection by the pathogen. Trans. Br. Mycol. Soc. 43:489-505.
36. Paul, P. A., El-Allaf, S. M., Lipps, P. E., and Madden, L. V. 2004. Rain splash dispersal of Gibberella zeae within wheat canopies in Ohio. Phytopathology 94:1342-1349

37. Peeters, L. Y. K., Soto-Pinto, L., Perales, H., Montoya, G., and Ishiki, M. 2003. Coffee production, timber, and firewood in traditional and Ingashaded plantations in Southern Mexico. Agric. Ecosyst. Environ. 95:481493.

38. Phiri, N. A., Hillocks, R. J., and Jeffries, P. 2001. Incidence and severity of coffee disease in smallholder plantations in northern Malawi. Crop Prot. 20:325-332.

39. Rapilly, F. 1991. L'épidémiologie en pathologie végétale: Mycoses aériennes. Institut National de la Recherche Agronomique.

40. Reddy, Y. T. N., Kurian, R. M., Ramachander, P. R., Singh, G., and Kohli, R. R. 2003. Long-term effects of rootstocks on growth and fruit yielding patterns of "Alphonso" mango (Mangifera indica L.). Sci. Hortic. 97:95108.

41. Schroth, G., Krauss, U., Gasparotto, L., Duarte, Aguilar, J. A., and Vohland, K. 2000. Pests and diseases in agroforestry systems of the humid tropics. Agrofor. Syst.50:199-241.

42. Swinburne, T. R. 1983. Quiescent infections in post-harvest diseases. Pages 1-21 in: Post-harvest Pathology of Fruits and Vegetables. C. Denis, ed. Academic Press, London.

43. Timmer, L. W., Darhower, H. M., Zitko, S. E., Peever, T. L., Ibanez, A. M., and Bushong, P. M. 2000. Environmental factors affecting the severity of Alternaria brown spot of citrus and their potential use in timing fungicide applications. Plant Dis. 84:638-643.

44. Vaast, P., Bertrand, B., Perriot, J.-J., Guyot, B., and Genard, M. 2006. Fruit thinning and shade improve bean characteristics and beverage quality of coffee (Coffea arabica L.) under optimal conditions. J. Sci. Food Agric. 86:197-204.

45. Van Der Graaf, N. A. 1992. Coffee berry disease. Pages 202-230 in: Plant Diseases of International Importance, Vol. 6. A. N. Mukhopadhyay, J. Kuman, U. S. Singh, and H. S. Chaube, eds. Englewood Cliffs, Prentice Hall, NJ.

46. Waller, J. M. 1972. Water-borne spore dispersal in coffee berry disease and it's relation to control. Ann. Appl. Biol. 71:1-18.

47. Waller, J. M., Bridge, P. D., Black, R., and Hakiza, G. 1993. Characterisation of the coffee berry disease pathogen, Colletotrichum kahawae pp. nov. Mycology 97:989-994.

48. Yang, X., Madden, L. V., Wilson, L. L., and Ellis, M. A. 1991. Application of the diffusion equation for modelling splash dispersal of pointsource pathogens. New Phytol. 118:295-301.

49. Yang, X., Madden, L. V., Wilson, L. L., and Ellis, M. A. 1990. Effects of surface topography and rain intensity on splash dispersal of Colletotrichum acutatum. Phytopathology 80:1115-1120.

50. Zadoks, J. C., and Schein, R. D. 1979. Epidemiology and Plant Disease Management. Oxford University Press, New York. 